\title{
Response of the benthic foraminiferal community to a simulated short-term phytodetritus pulse in the abyssal North Pacific
}

\author{
Annekatrin J. Enge ${ }^{1, *}$, Hidetaka Nomaki ${ }^{2}$, Nanako O. Ogawa ${ }^{2}$, Ursula Witte ${ }^{3}$, \\ Markus M. Moeseneder ${ }^{3,4}$, Gaute Lavik ${ }^{5}$, Naohiko Ohkouchi ${ }^{2}$, Hiroshi Kitazato ${ }^{2}$, \\ Michal Kučera ${ }^{1}$, Petra Heinz ${ }^{1}$ \\ ${ }^{1}$ Department for Geosciences, University of Tübingen, Hölderlinstrasse 12, 72074 Tübingen, Germany \\ ${ }^{2}$ Institute of Biogeosciences, Japan Agency for Marine-Earth Science and Technology (JAMSTEC), 2-15 Natsushima-cho, \\ Yokosuka, 237-0061, Japan \\ ${ }^{3}$ Oceanlab, University of Aberdeen, Newburgh, Aberdeenshire AB41 6AA, UK \\ ${ }^{4}$ National Oceanography Centre, University of Southampton, Waterfront Campus, European Way, Southampton SO14 3ZH, UK \\ ${ }^{5}$ Max Planck Institute for Marine Microbiology, Celsiusstrasse 1, 28359 Bremen, Germany
}

\begin{abstract}
Foraminifera are an important faunal element of the abyssal ecosystem and largely depend on deposited particulate organic matter from the photic zone to sustain their metabolism for growth and reproduction. However, their role in the carbon cycle in deep-sea sediments is insufficiently studied. We investigated benthic foraminifera at Station M (4000 m depth) in the Northeast Pacific and assessed the response of individual species to a simulated phytodetritus pulse during an in situ feeding experiment. Sediments were incubated for $4 \mathrm{~d}$ with ${ }^{13} \mathrm{C}$-labeled diatoms (Thalassiosira weissflogii) applied to the sediment surface. The living foraminiferal community $(>0.063 \mathrm{~mm}$ ) of the upper $3 \mathrm{~cm}$ contained $>100$ species and was strongly dominated by a few taxa of soft-walled saccamminids. Population density of the entire living foraminiferal community was highest at the sediment surface (mean $\pm \mathrm{SD}=279 \pm 72$ ind. $10 \mathrm{~cm}^{-3}$ in background and ${ }^{13} \mathrm{C}$-incubated cores) and decreased gradually with depth. Large differences were observed in the uptake of the algal material among species and between depth levels. During the experiment, $0.82 \mathrm{mg} \mathrm{C} \mathrm{m}{ }^{-2}$ were ingested, mainly by calcareous ( $\left.60 \%\right)$ and agglutinated $(\sim 40 \%)$ foraminifera. Uptake was highest at the sediment surface and 3 to 5 times less in deeper sediment horizons. Despite clear signs of vitality and a strong representation in the foraminiferal community, none of the soft-walled species showed a noticeable response to the offered algal material. We conclude that soft-walled foraminifera may not be important to the short-term phytodetrital matter cycling at the abyssal sea floor.
\end{abstract}

KEY WORDS: Deep sea $\cdot$ North Pacific $\cdot$ In situ feeding experiment $\cdot \delta^{13} \mathrm{C} \cdot$ Isotopic labeling Benthic foraminifera $\cdot$ Carbon remineralization $\cdot$ Soft-walled saccamminid

\section{INTRODUCTION}

In the deep sea, foraminifera are an important component of the benthic community and can account for $50 \%$ or more of the eukaryotic biomass (Gooday et al. 1992). Altenbach (1992) estimated that 6 to $10 \%$ of the total flux of organic matter to the sediment surface in the deep sea is ingested by benthic foraminifera. In the deeper regions of the oceans $(>1000 \mathrm{~m}$ depth), the biomass of benthic foraminifera is posi- 
tively correlated with the flux of organic matter (Altenbach 1992, Altenbach \& Struck 2001). Mainly controlled by oxygen concentration and food availability, individual foraminiferal species have adapted to different environmental conditions and display specific microhabitat preferences within the sediment (Corliss \& Emerson 1990, Jorissen et al. 1995). Differences in the amount and delivery pattern of phytodetritus have a direct impact on benthic foraminifera (Gooday \& Lambshead 1989, Lambshead \& Gooday 1990) in controlling their abundance and the distribution of species (Thiel et al. 1988, Gooday 1993).

Feeding experiments using isotopically-labeled food (e.g. with ${ }^{13} \mathrm{C}$ ) and tracking the ingested tracer by changes in the isotopic composition of the cytoplasm have become an effective tool to study in situ phytodetrital carbon uptake by these organisms (Blair et al. 1996). Such approaches have been successfully operated in foraminifera within different habitats: the intertidal flat in the southern North Sea (Moodley et al. 2000), a fjord in Norway (Sweetman et al. 2009), the bathyal region of the Northwest Pacific (Nomaki et al. 2005b, 2006, 2009, 2011), and the abyssal North Atlantic (Moodley et al. 2002, Witte et al. 2003b). These studies showed that benthic foraminifera within each particular habitat contributed to carbon cycling but with large differences in the degree of uptake. However, it remains unclear why such differences in carbon uptake occur, to what degree the results can be generalized to other regions, and how the ecological preferences of individual species affect the rate and pattern of carbon uptake in benthic foraminifera.

We aimed to investigate the contribution of foraminifera to carbon remineralization in the abyssal ocean. Results will give more information about the role of foraminifera within the global marine carbon cycle, also in comparison to other benthic organisms and different marine habitats. We chose Station M (Stn M) in the abyssal Northeast Pacific to perform the in situ feeding experiment.

The extensive study of benthic and pelagic processes at Stn M over the last 2 decades by K. Smith and colleagues has created a complex picture of the system and the influencing factors, worth for designing a model for deep-sea processes (Smith et al. 2006) and helpful in interpreting the abiotic influence on the foraminiferal assemblage. The role of benthic organisms in carbon cycling at this abyssal site has been investigated, though predominately on macrofauna (e.g. Sweetman \& Witte 2008a,b). Drazen et al. (1998) reported a positive long-term response of the foraminiferal density towards food availability at Stn $\mathrm{M}$, but considered only specimens $>300 \mu \mathrm{m}$ in size and investigated the numerical change of foraminifera as a taxon rather than measuring uptake or looking at single species. In comparison, we explored the role of benthic foraminifera $>63 \mu \mathrm{m}$ and concentrated on specific rates of species. Thus, a very different assemblage was examined, as we also included soft-walled species as an important part of the investigated fauna.

Observations on population densities in the central North Pacific (Hessler \& Jumars 1974, Bernstein et al. 1978, Snider et al. 1984) and in the Northeast Pacific at Stn M (Drazen et al. 1998) have shown the numerical importance of benthic foraminifera among the sediment-inhabiting fauna in this region, indicating their important contribution to carbon cycling here. Especially monothalamous soft-walled foraminifera are important components of deep-sea sediments (Gooday 1994), in particular in oligotrophic areas and below the carbonate compensation depth with an assumed diet of refractory organic material and bacteria (Gooday et al. 2008). Despite their numerical significance, the taxonomy, ecology, and role of monothalamous soft-walled foraminifera in deep-sea sediments remain mostly unknown and require further study. This will be the first time that soft-walled foraminifera are included in a feeding experiment using isotopic labeling. We investigated and compared species-specific ingestion rates of benthic foraminifera, focusing on single morphotypes of softwalled species because of their numerical dominance in the foraminiferal fauna. High measurement sensitivity allowed us to achieve the first species-level analysis of a soft-walled fauna from the abyssal plain.

The marine diatom Thalassiosira weissflogii was chosen as a potential food source in our experiment. This species is a cosmopolitan bloom-forming taxon which has been previously used in a series of deepsea feeding experiments, and the genus is commonly found in detrital aggregates at the investigation site, Stn M (Beaulieu \& Smith 1998).

\section{MATERIALS AND METHODS}

\section{Study site}

The feeding experiment was carried out at Stn M $\left(34^{\circ} 50^{\prime} \mathrm{N}, 123^{\circ} 00^{\prime} \mathrm{W}\right)$ in the abyssal Northeast Pacific in September 2007. This site is located $220 \mathrm{~km}$ west off Point Conception, California, USA (Fig. 1), at the base of the Monterey Deep-Sea Fan and has 


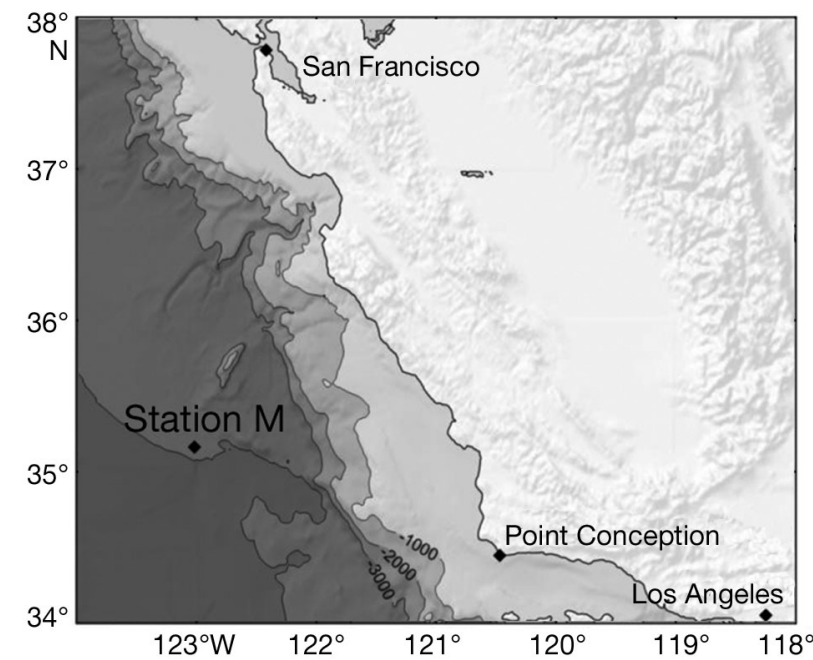

Fig. 1. 'Station M' off California, USA, site of the in situ feeding experiment

been described in detail by Smith \& Druffel (1998). The sea floor at Stn $M$ shows little topographical relief $\left(<100 \mathrm{~m}\right.$ over $\left.1600 \mathrm{~km}^{2}\right)$, has silty-clayey sediments (Smith \& Druffel 1998), and dissolved oxygen is present in the pore water to $\sim 3 \mathrm{~cm}$ sediment depth (Reimers 1987).

Phytoplankton primary production along the coast of California occurs from spring to fall (Smith \& Druffel 1998), with a net production range of 200 to $1200 \mathrm{mg} \mathrm{C} \mathrm{m}^{-2} \mathrm{~d}^{-1}$ (Ruhl \& Smith 2004, Smith et al. 2008). The export of photosynthetically derived organic matter and the abyssal particulate organic carbon (POC) flux at Stn M are correlated (Smith et al. 2008) and exhibit both intra- and inter-annual variability (Smith et al. 1994, 2001, 2006, Smith \& Druffel 1998). The POC flux measured at $3000 \mathrm{~m}$ depth from 1998 to 2006 ranged between 0 and $70 \mathrm{mg} \mathrm{C} \mathrm{m}{ }^{-2} \mathrm{~d}^{-1}$, with a mean of $\sim 10 \mathrm{mg} \mathrm{C} \mathrm{m}^{-2} \mathrm{~d}^{-1}$ (Smith et al. 2008, 2009). Hence, phytodetritus is available to benthic organisms only during a limited period of time.

\section{Preparation of ${ }^{13} \mathrm{C}$-labeled algae}

The diatom Thalassiosira weissflogii was cultured at $15^{\circ} \mathrm{C}$ (16 h light:8 $\mathrm{h}$ dark) in artificial seawater (Grasshoff et al. 1999) amended with $\mathrm{f} / 2$ medium (CCMP) and ${ }^{13} \mathrm{C}$-bicarbonate $\left(99\right.$ atom $\%{ }^{13} \mathrm{C}$-enriched $\mathrm{NaHCO}_{3}$, Cambridge Isotope Laboratories). Algae were harvested by centrifugation (1400 $g, 15 \mathrm{~min}$ ) and washed 3 times with sterile-filtered $(0.2 \mu \mathrm{m})$ seawater to remove excess $\mathrm{NaH}^{13} \mathrm{CO}_{3}$ and any dissolved organic ${ }^{13} \mathrm{C}$ exuded by the diatoms. The harvest was quick-frozen in liquid nitrogen to avoid cell rupture and stored at $-80^{\circ} \mathrm{C}$ until freeze-drying. The dried algae contained 53.45 atom $\%{ }^{13} \mathrm{C}$ (measured on a Flash EA 1112 Series Elemental Analyzer connected via a Conflo III to a Delta ${ }^{\text {Plus }}$ Advantage isotope ratio mass spectrometer, Thermo Finnigan).

\section{Experimental setup}

The in situ feeding experiment was carried out during the 'PULSE 53' cruise of the RV 'Western Flyer' at $3953 \mathrm{~m}$ depth with 2 Oceanlab spreader systems (290 $\mathrm{mm}$ inner diameter). The plexiglass tubes of the spreaders were deployed at the sea floor and pushed into the sediment by the remotely operated vehicle ROV 'Tiburon' until standing firmly upright. Each spreader lid held a container with a suspension of $215 \mathrm{mg}$ of ${ }^{13} \mathrm{C}$-labeled freeze-dried Thalassiosira weissflogii, which was applied to the enclosed sediment surface by pushing a plunger that subsequently releases the algae. The lids of the spreaders were removed after the algal material had entirely deposited on the sediment surface. The added algal biomass corresponds to about a quarter of the annual POC flux at Stn M (e.g. Smith et al. 2008, 2009) and can be considered as a realistic simulation of a rapidly sinking bloom event. Incubation of sediments with labeled algae lasted $4 \mathrm{~d}$. The sufficient amount of food and the open system with continuous water exchange guaranteed a set up very similar to natural conditions. After the incubation period, 1 push core (plexiglass tube, $70 \mathrm{~mm}$ internal diameter) from each of the 2 spreader devices and 2 additional push cores from the surrounding sediment were recovered by the ROV. Sediment cores were immediately sliced $(0-1,1-2,2-3 \mathrm{~cm})$ on board the research vessel and kept frozen at $-20^{\circ} \mathrm{C}$. We concentrated on the oxygenated upper $3 \mathrm{~cm}$ of sediment, as foraminiferal assemblages of abyssal sediments are dominated by epifaunal and shallow infaunal species (Corliss \& Emerson 1990, Gooday 1994).

\section{Sample preparation}

In the laboratory (University of Tübingen), sediment samples were thawed and washed over a mesh $(63 \mu \mathrm{m})$ with artificial seawater of 34 to $35 \mathrm{psu}(23.4 \mathrm{~g}$ $\mathrm{NaCl}, 4.0 \mathrm{~g} \mathrm{MgSO}_{4} \times 7 \mathrm{H}_{2} \mathrm{O}, 0.8 \mathrm{~g} \mathrm{KCl}, 0.26 \mathrm{~g} \mathrm{CaCl}_{2}$, and distilled water up to $1 \mathrm{l}$ final volume). After sieving, residues were frozen at $-20^{\circ} \mathrm{C}$ until further pro- 
cessing. Separation of living and dead specimens was based on visual assessment of cytoplasm presence (Moodley et al. 2002, Nomaki et al. 2005b, 2006, Sweetman et al. 2009) and the degree to which it filled the test. Foraminifera were wet-picked under cooled conditions and identified to species level if possible. We had to adjust the counting method for several types of agglutinated groups: (1) counts of fragments of multi-chambered specimens (Reophax, Hormosinella) were normalized to complete specimens by dividing fragment counts by the maximum number of chambers observed in intact tests of each species, (2) fragments of tubular-shaped species (e.g. Rhabdammina, Saccorhiza) were converted to individual counts by dividing the number of fragments by 3 (Kurbjeweit et al. 2000). All individuals of species that could not be analyzed separately because of insufficient biomass were pooled into 1 taxonomic group and are referred to as 'other.' In agglutinated foraminifera, multiple species were grouped together based on their general morphology, related to possible habitat adaptations. The group 'tubular' agglutinates includes specimens of the taxon Astrorhizida (except Saccamminidae), while members of the taxa Lituolida, Trochamminida, and Textularida were pooled under 'non-tubular' agglutinated.

Before processing material for isotopic analysis, glassware and silver cups were combusted $\left(450^{\circ} \mathrm{C}\right.$, $5 \mathrm{~h}$ ), and picking tools were cleaned with a mixture of dichloromethane and methane $(1: 1, \mathrm{v}: \mathrm{v})$ to be organic free. All foraminifera were carefully brushed to remove organic matter on the outside of the test, washed twice in filtered artificial seawater, and then transferred into silver cups (each filled with $30 \mu \mathrm{l}$ of filtered seawater). Subsequently, the filled cups were dried at $50^{\circ} \mathrm{C}$ for several hours before adding $20 \mu \mathrm{l}$ hydrochloric acid $(6.25 \%)$ to remove all calcium carbonate in the samples. To completely dry the samples, heating and acidification were repeated once more, and samples were kept at $50^{\circ} \mathrm{C}$ for $3 \mathrm{~d}$.

Measurements of the total organic carbon (TOC) content and the ratio of the carbon isotopes $\left({ }^{13} \mathrm{C}:{ }^{12} \mathrm{C}\right)$ of the foraminiferal cytoplasm were realized at the Japanese Agency for Marine-Earth Science and Technology (JAMSTEC) and at the Max Planck Institute (MPI) for Marine Microbiology in Bremen, Germany. At JAMSTEC, acidified samples in silver capsules were further wrapped with a tin capsule before elemental analyzer/isotopic ratio mass spectrometer (EA/IRMS) analysis. Both capsules were pre-cleaned by a methanol:dichloromethane $(1: 1, \mathrm{v}: \mathrm{v})$ solution. The required minimum amount of TOC for reliable isotopic measurements was either $700 \mathrm{ng}$ (JAM-
STEC; Ogawa et al. 2010) or $10 \mu$ (MPI). To obtain species-level analysis, we pooled individuals of 1 species or group from both cores of identical treatment $\left({ }^{13} \mathrm{C}\right.$-incubation or background) at the same sediment depth. Therefore, no replicates were measured and not all species or groups were analyzed at each depth level.

\section{Calculation of carbon uptake}

The carbon isotope ratio $\left({ }^{13} \mathrm{C}:{ }^{12} \mathrm{C}\right)$ of foraminiferal cytoplasm was measured against the international Vienna Pee Dee Belemnite standard (VPDB) and is expressed as the difference between sample and standard in the $\delta$-notation: $\delta^{13} \mathrm{C}(\%)=\left[\left({ }^{13} \mathrm{C}:{ }^{12} \mathrm{C}_{\text {sample }}\right) /\right.$ $\left.\left({ }^{13} \mathrm{C}:{ }^{12} \mathrm{C}_{\mathrm{VPDB}}\right)-1\right] \times 10^{3}$. Specific uptake of labeled ${ }^{13} \mathrm{C}$ by foraminifera was calculated as excess (above background) and is expressed in the $\Delta$-notation: $\Delta \delta^{13} \mathrm{C}(\%)=\delta^{13} \mathrm{C}_{\text {sample }}-\delta^{13} \mathrm{C}_{\text {background }}$. Carbon uptake was calculated as the product of the excess atom \% ${ }^{13} \mathrm{C}$ and the carbon content of the cytoplasm in the sample, divided by the atom $\%{ }^{13} \mathrm{C}$ of the labeled algae: C-uptake $(\mu \mathrm{g} \mathrm{C})=\left[\left(\right.\right.$ atom $\%{ }^{13} \mathrm{C}_{\text {sample }}-$ atom $\%$ $\left.{ }^{13} \mathrm{C}_{\text {background }}\right) / 53.45$ atom\% $\%$ ( TOC $\left._{\text {sample }}\right)$ (Sweetman \& Witte 2008a,b, Sweetman et al. 2009).

The natural $\delta^{13} \mathrm{C}$ variation was calculated for every foraminiferal species from the mean background $\delta^{13} \mathrm{C}$ value by addition and subtraction of the standard deviation (SD). The resultant species-specific range was then used to separate significant enrichment from natural $\delta^{13} \mathrm{C}$ variation in species, i.e. calculated $\Delta \delta^{13} \mathrm{C}$ values within the range were excluded from further uptake estimation. Error terms stated in combination with calculated data (e.g. on foraminiferal abundance, TOC content) are SD.

\section{RESULTS}

\section{Abundance and biomass of living foraminifera}

Highest numbers of living foraminifera were found at the sediment surface $\left(279 \pm 72\right.$ ind. $\left.10 \mathrm{~cm}^{-3}\right)$, and abundances declined with sediment depth. Altogether, $>100$ species were identified, and the assemblage was highly dominated by a few taxa. Softwalled foraminifera were the most abundant group at all 3 sediment depths (Table 1) and contributed up to $71 \%$ of the specimens in the deeper layers. These foraminifera (Saccamminidae, Astrorhizida) are monothalamous saccamminids with variable external morphology. The taxonomic classification of this group of 
agglutinated foraminifera remains uncertain because of lack of characters and poor taxonomic knowledge. So we divided them into Saccamminid sp. 1 to 4 on the basis of the shape and length of the 'neck' and the composition of the outer wall (smooth and shiny, coarse, or coarse with small particles sticking to the wall). This group will hereafter be referred to as 'softwalled' and will be handled separately from the remaining agglutinated species. Agglutinated foraminifera other than the monothalamous saccamminids were also present at all depths and showed the highest diversity (68 taxa). Calcareous foraminifera with 45 taxa showed an abundance maximum in the top $\mathrm{cm}$ and a minimum at $1-2 \mathrm{~cm}$ depth. Their total population density corresponds to only $10 \%$ of the total foraminiferal assemblage (10 to 34 ind. $10 \mathrm{~cm}^{-3}$ ).

In general, agglutinated foraminifera contributed most to the foraminiferal biomass at 0-2 $\mathrm{cm}$ depth (Table 1), whereas calcareous and soft-walled foraminifera showed less but comparatively similar con-

Table 1. Foraminiferal numbers and biomass at Station $M$ in background (core nos. 1 \& 2) and incubated sediment cores (core nos. 3 \& 4). TOC: total organic carbon

\begin{tabular}{|c|c|c|c|c|c|c|c|}
\hline \multirow{2}{*}{$\begin{array}{l}\text { Depth } \\
\text { (cm) }\end{array}$} & \multirow{2}{*}{$\begin{array}{c}\text { Core } \\
\text { no. }\end{array}$} & \multicolumn{3}{|c|}{ Abundance (n $10 \mathrm{~cm}^{-2}$ ) } & \multicolumn{3}{|c|}{ Biomass $\left(\mu \mathrm{g}\right.$ TOC $\left.10 \mathrm{~cm}^{-2}\right)$} \\
\hline & & $\begin{array}{l}\text { Agglu- } \\
\text { tinated }\end{array}$ & $\begin{array}{l}\text { Calca- } \\
\text { reous }\end{array}$ & $\begin{array}{c}\text { Soft- } \\
\text { walled }\end{array}$ & $\begin{array}{l}\text { Agglu- } \\
\text { tinated }\end{array}$ & $\begin{array}{l}\text { Calca- } \\
\text { reous }\end{array}$ & $\begin{array}{c}\text { Soft- } \\
\text { walled }\end{array}$ \\
\hline \multirow[t]{4}{*}{$0-1$} & 1 & 72 & 19 & 103 & 10 & 5 & 6 \\
\hline & 2 & 118 & 36 & 152 & 20 & 11 & 8 \\
\hline & 3 & 112 & 31 & 112 & 20 & 10 & 6 \\
\hline & 4 & 168 & 52 & 144 & 36 & 9 & 7 \\
\hline \multirow[t]{4}{*}{$1-2$} & 1 & 30 & 8 & 116 & 5 & 2 & 8 \\
\hline & 2 & 42 & 18 & 119 & 8 & 9 & 8 \\
\hline & 3 & 94 & 11 & 149 & 20 & 3 & 8 \\
\hline & 4 & 63 & 5 & 81 & 13 & 2 & 6 \\
\hline \multirow{4}{*}{$2-3$} & 1 & 27 & 17 & 165 & 3 & 9 & 11 \\
\hline & 2 & 14 & 19 & 99 & 2 & 9 & 7 \\
\hline & 3 & 35 & 13 & 92 & 8 & 5 & 5 \\
\hline & 4 & 44 & 12 & 78 & 9 & 3 & 4 \\
\hline
\end{tabular}

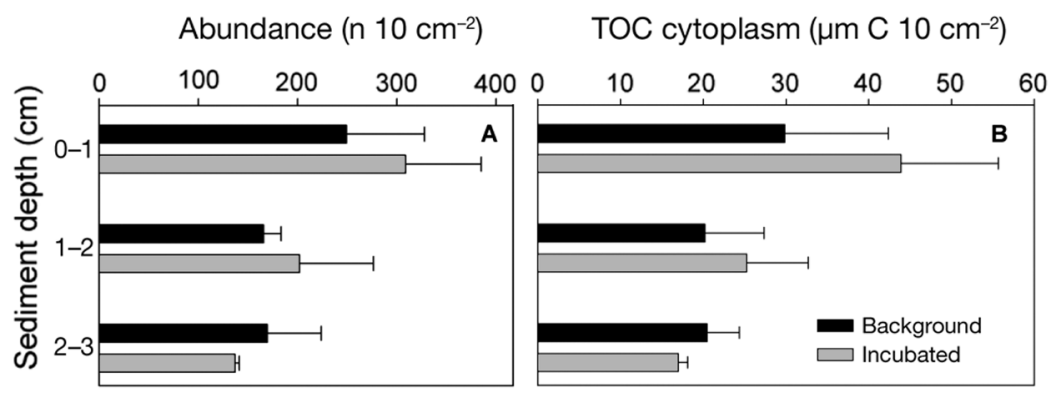

Fig. 2. (A) abundance (n $10 \mathrm{~cm}^{-2}$ ) and (B) biomass ( $\mu$ g total organic carbon, TOC, $10 \mathrm{~cm}^{-2}$ ) of living foraminifera from background and ${ }^{13} \mathrm{C}$-incubated sediments (mean $+\mathrm{SD}, 2$ cores each) tribution to the overall biomass. Abundance and biomass of the living foraminiferal populations did not differ between ${ }^{13} \mathrm{C}$-incubated and background sediments (paired $t$-tests, $\mathrm{n}=4, \mathrm{p}>0.05$ ) (Fig. 2A,B).

In total, 2 types of monothalamous saccamminids, 6 calcareous and 8 agglutinated species occurred in sufficient numbers and biomass to allow speciesspecific isotope analyses.

\section{Organic carbon content in foraminiferal cytoplasm}

Carbon content for 1 individual was obtained by dividing measured total TOC content of pooled individuals (Table 2) through the number of measured specimens. Mean TOC content of 1 foraminifer ranged between 0.04 and $52.01 \mu \mathrm{g}$ (Table 2). Soft-walled and calcareous foraminifera had a mean TOC content of $0.07 \pm 0.02$ and $0.20 \pm 0.19 \mu \mathrm{g}$ ind $^{-1}$, respectively (from both sediment treatments). Agglutinated foraminifera showed a higher mean TOC $(1.62 \pm 8.52 \mu \mathrm{g})$. The largest difference in the TOC content per individual between sediment levels was found in the group 'other tubular agglutinated' in the ${ }^{13} \mathrm{C}$-incubated sediment (Table 2). TOC content did not differ significantly between foraminiferal cytoplasm from ${ }^{13} \mathrm{C}$-incubated and background sediment (paired $t$-test for all species/groups and depths: $t=-0.44, \mathrm{p}=0.66, \mathrm{n}=16$ ). Of 16 single species/groups tested, only Cribrostomoides subglobosum showed a significant difference between the 2 core types (paired $t$-test: $t=-275.37, \mathrm{p}=0.02$ ) with higher TOC content in the ${ }^{13} \mathrm{C}$-incubated cores.

\section{Natural isotopic signatures}

The isotopic signatures of benthic foraminifera from background sediment exhibited a mean $\delta^{13} \mathrm{C}$ of $-19.5 \pm 2.9 \%$ (Fig. 3, Table 2) and were slightly heavier than the $\delta^{13} \mathrm{C}$ of sedimentary TOC with an average of $-22.2 \%$ (U. Witte et al. unpublished data). The group 'other calcareous' displayed the overall lightest $(-23.2 \%$, at $0-1 \mathrm{~cm})$ and heaviest value $(-7.1 \%$, at $1-2 \mathrm{~cm})$. Differences in the 
Table 2. Total organic carbon content (TOC) content, isotopic signatures and carbon uptake of foraminifera from background and incubated sediments. $\mathrm{n}$ : number of individuals; $\mathrm{n}$ for tubular agglutinated specimens (marked with ${ }^{*}$ ) represents number of fragments. Single TOC values represent measurement of pooled samples divided by n. Bkgr. \& inc. TOC: mean TOC \pm SD, combined from background (bkgr.) and incubated (inc.) sediments across 0 to $3 \mathrm{~cm}$ depth. Missing background $\delta^{13} \mathrm{C}$ signatures were substituted as follows: C. subglobosum (1-2 cm): mean of values from $0-1$ and $2-3 \mathrm{~cm}$; Saccorhiza ramosa $(0-1,2-3 \mathrm{~cm})$ : same value as for $1-2 \mathrm{~cm}_{i}$ I. tumidula $(0-1 \mathrm{~cm})$ : averaged from all other calcareous signatures at $0-1 \mathrm{~cm}$; C. cancellata $(0-1 \mathrm{~cm})$ : averaged from the values presented by Nomaki et al. (2006). ${ }^{* *}$ : excess $\left(\Delta \delta^{13} \mathrm{C}\right)$ which does not exceed natural background variation (see

'Materials and methods'). nd: no data

\begin{tabular}{|c|c|c|c|c|c|c|c|c|c|c|}
\hline & \multirow[t]{2}{*}{ Depth } & \multicolumn{3}{|c|}{$\begin{array}{l}\text { Background } \\
\text { sediment }\end{array}$} & \multicolumn{3}{|c|}{$\begin{array}{c}{ }^{13} \mathrm{C} \text {-incubated } \\
\text { sediment }\end{array}$} & \multirow{2}{*}{$\begin{array}{c}\text { Bkgr. \& inc. } \\
\text { TOC } \\
\text { ( } \mu \mathrm{g} \text { per ind.) }\end{array}$} & \multirow[t]{2}{*}{$\begin{array}{c}\Delta \delta^{13} \mathrm{C} \\
(\% \circ)\end{array}$} & \multirow[t]{2}{*}{$\begin{array}{l}\text { C uptake } \\
\left(\mu \mathrm{g} \mathrm{C} \mathrm{m}^{-2}\right)\end{array}$} \\
\hline & & $\mathrm{n}$ & $\begin{array}{c}\text { TOC } \\
(\mu g \\
\text { per ind.) }\end{array}$ & $\begin{array}{c}\delta^{13} \mathrm{C} \\
(\% \circ)\end{array}$ & $\mathrm{n}$ & $\begin{array}{l}\text { TOC } \\
(\mu g \\
\text { per ind. }\end{array}$ & $\begin{array}{l}\delta^{13} \mathrm{C} \\
(\% \circ)\end{array}$ & & & \\
\hline \multicolumn{11}{|l|}{ Soft-walled taxa } \\
\hline \multirow[t]{3}{*}{ Saccamminid sp. 3} & $0-1 \mathrm{~cm}$ & 263 & 0.06 & -21.6 & 443 & 0.08 & -17.8 & $0.08 \pm 0.01$ & 3.8 & 0.07 \\
\hline & $1-2 \mathrm{~cm}$ & 176 & 0.10 & -20.6 & 174 & 0.09 & -19.6 & & 1.0 & 0.05 \\
\hline & $2-3 \mathrm{~cm}$ & 49 & 0.08 & -21.0 & 133 & 0.09 & -19.1 & & 1.9 & 0.08 \\
\hline \multirow[t]{3}{*}{ Saccamminid sp. 4} & $0-1 \mathrm{~cm}$ & 453 & 0.04 & -20.9 & 520 & 0.04 & -16.5 & $0.05 \pm 0.01$ & 4.4 & 0.58 \\
\hline & $1-2 \mathrm{~cm}$ & 546 & 0.04 & -19.1 & 526 & 0.06 & -20.2 & & $-1.1^{* *}$ & nd \\
\hline & $2-3 \mathrm{~cm}$ & 726 & 0.04 & -19.2 & 357 & 0.07 & -18.8 & & $0.5^{* *}$ & nd \\
\hline \multirow[t]{3}{*}{ Other soft-walled } & $0-1 \mathrm{~cm}$ & 90 & 0.08 & -19.2 & 102 & 0.12 & -27.1 & $0.07 \pm 0.03$ & $-7.9^{* *}$ & nd \\
\hline & $1-2 \mathrm{~cm}$ & 72 & 0.07 & -18.7 & 92 & 0.06 & -17.9 & & 0.8 & 0.01 \\
\hline & $2-3 \mathrm{~cm}$ & 92 & 0.06 & -19.2 & 84 & 0.05 & -17.4 & & 1.8 & 0.02 \\
\hline Total soft-walled taxa & $0-3 \mathrm{~cm}$ & & & & & & & $0.07 \pm 0.02$ & & 0.82 \\
\hline \multicolumn{11}{|l|}{ Calcareous taxa } \\
\hline \multirow[t]{3}{*}{ Epistominella pusilla } & $0-1 \mathrm{~cm}$ & 37 & 0.06 & -17.8 & 83 & 0.05 & 145 & $0.07 \pm 0.02$ & 162.8 & 1.89 \\
\hline & $1-2 \mathrm{~cm}$ & 15 & 0.10 & -18.7 & nd & nd & nd & & nd & nd \\
\hline & $2-3 \mathrm{~cm}$ & 27 & 0.06 & -20.0 & 10 & 0.09 & -4.1 & & 15.9 & 0.08 \\
\hline \multirow[t]{3}{*}{ Globocassidulina subglobosa } & $0-1 \mathrm{~cm}$ & 30 & 0.03 & -15.9 & 70 & 0.08 & -10.3 & $0.09 \pm 0.04$ & 5.6 & 0.08 \\
\hline & $1-2 \mathrm{~cm}$ & 14 & 0.14 & -21.9 & 18 & 0.18 & -12.9 & & 9.0 & 0.05 \\
\hline & $2-3 \mathrm{~cm}$ & 13 & 0.09 & -20.9 & nd & nd & nd & & nd & nd \\
\hline Ioanella tumidula & $0-1 \mathrm{~cm}$ & nd & nd & $(-19.7)$ & 25 & 0.06 & -7.5 & 0.056 & 12.2 & 0.06 \\
\hline \multirow[t]{2}{*}{ Melonis barleeanum } & $0-1 \mathrm{~cm}$ & 13 & 0.21 & -17.7 & 6 & 0.46 & -17.0 & $0.37 \pm 0.22$ & 0.7 & 0.01 \\
\hline & $1-2 \mathrm{~cm}$ & 9 & 0.64 & -17.9 & 13 & 0.18 & -17.6 & & 0.3 & 0.00 \\
\hline \multirow[t]{3}{*}{ Other calcareous } & $0-1 \mathrm{~cm}$ & 87 & 0.35 & -23.2 & 86 & 0.72 & 1636.2 & $0.30 \pm 0.22$ & 1659.4 & 342.58 \\
\hline & $1-2 \mathrm{~cm}$ & 25 & 0.17 & -7.1 & 12 & 0.17 & nd & & nd & nd \\
\hline & $2-3 \mathrm{~cm}$ & 20 & 0.27 & -19.7 & 25 & 0.13 & nd & & nd & nd \\
\hline Total calcareous taxa & $0-3 \mathrm{~cm}$ & & & & & & & $0.20 \pm 0.19$ & & 344.75 \\
\hline \multicolumn{11}{|l|}{ Agglutinated taxa } \\
\hline \multirow[t]{3}{*}{ Adercotryma glomerata } & $0-1 \mathrm{~cm}$ & 70 & 0.07 & -22.6 & 91 & 0.04 & 141.5 & $0.067 \pm 0.03$ & 164.0 & 1.57 \\
\hline & $1-2 \mathrm{~cm}$ & 16 & 0.11 & -18.5 & nd & nd & nd & & nd & nd \\
\hline & $2-3 \mathrm{~cm}$ & 16 & 0.09 & -18.7 & 12 & 0.04 & -9.6 & & 9.1 & 0.03 \\
\hline Cribrostomoides subglobosum & $0-1 \mathrm{~cm}$ & 9 & 0.38 & -19.0 & 44 & 0.16 & 225 & $0.25 \pm 0.13$ & 244.0 & 5.06 \\
\hline & $1-2 \mathrm{~cm}$ & 11 & 0.41 & -19.5 & 40 & 0.19 & nd & & nd & nd \\
\hline & $2-3 \mathrm{~cm}$ & nd & nd & $(-19.3)$ & 15 & 0.13 & -12.6 & & 6.7 & 0.04 \\
\hline Cyclammina cancellata & $0-1 \mathrm{~cm}$ & nd & nd & $(-19.8)$ & 1 & 52.01 & -7.7 & 52.01 & 12.1 & 1.69 \\
\hline Hormosinella guttifera & $0-1 \mathrm{~cm}$ & 74 & 0.05 & -18.0 & 99 & 0.06 & 8.7 & $0.11 \pm 0.12$ & 26.7 & 1.65 \\
\hline & $1-2 \mathrm{~cm}$ & 25 & 0.07 & -16.7 & 27 & 0.06 & 39.0 & & 55.7 & 0.84 \\
\hline & $2-3 \mathrm{~cm}$ & 15 & 0.34 & -19.6 & 28 & 0.04 & 3.4 & & 23.0 & 0.32 \\
\hline Trochammina globigeriniformis & $0-1 \mathrm{~cm}$ & 11 & 0.10 & -16.9 & 35 & 0.14 & 2030 & $0.09 \pm 0.03$ & 2046.9 & 44.03 \\
\hline & $1-2 \mathrm{~cm}$ & 16 & 0.07 & -18.5 & 30 & 0.05 & nd & & nd & nd \\
\hline Trochammina inflata & $0-1 \mathrm{~cm}$ & 22 & 0.07 & -18.9 & 43 & 0.04 & 5.3 & $0.06 \pm 0.02$ & 24.2 & 0.22 \\
\hline Other non-tubular agglutinated & $0-1 \mathrm{~cm}$ & 255 & 0.18 & -21.5 & 383 & 0.14 & 485.8 & $0.14 \pm 0.04$ & 507.3 & 98.27 \\
\hline & $1-2 \mathrm{~cm}$ & 126 & 0.12 & -21.7 & 145 & 0.18 & 202.5 & & 224.2 & 30.44 \\
\hline & $2-3 \mathrm{~cm}$ & 108 & 0.17 & -18.7 & 141 & 0.07 & -11.7 & & 7.0 & 0.22 \\
\hline Rhabdammina abyssorum* & $0-1 \mathrm{~cm}$ & 266 & 0.32 & -21.4 & 443 & 0.30 & 23.2 & $0.29 \pm 0.07$ & 44.6 & 16.37 \\
\hline & $1-2 \mathrm{~cm}$ & 20 & 0.19 & -20.0 & 198 & 0.33 & -17.2 & & 2.8 & 0.62 \\
\hline Saccorhiza ramosa* & $0-1 \mathrm{~cm}$ & nd & nd & $(-17.4)$ & 4 & 4.38 & -18.1 & $1.95 \pm 1.69$ & $-0.7^{* *}$ & nd \\
\hline & $1-2 \mathrm{~cm}$ & 4 & 0.90 & -17.4 & 87 & 0.68 & 285.8 & & 303.2 & 49.46 \\
\hline & $2-3 \mathrm{~cm}$ & nd & nd & $(-17.4)$ & 10 & 1.85 & 813 & & 830.4 & 158.71 \\
\hline Other tubular agglutinated* & $0-1 \mathrm{~cm}$ & 150 & 0.59 & -20.3 & 173 & 0.73 & 292.8 & $1.04 \pm 1.33$ & 313.1 & 59.91 \\
\hline & $1-2 \mathrm{~cm}$ & 1 & 3.38 & -16.5 & nd & nd & nd & & nd & nd \\
\hline & $2-3 \mathrm{~cm}$ & 20 & 0.31 & -18.0 & 42 & 0.19 & -11.3 & & 6.7 & 0.27 \\
\hline Total agglutinated taxa & $0-3 \mathrm{~cm}$ & & & & & & & $1.62 \pm 8.52$ & & 469.71 \\
\hline
\end{tabular}


natural $\delta^{13} \mathrm{C}$ signature among sampling depths were largest within the group 'other calcareous,' Globocassidulina subglobosa, as well as for Adercotryma glomerata (Fig. 3). Mean natural $\delta^{13} \mathrm{C}$ signatures of foraminifera did not differ significantly ( 3 paired $t$ tests, $\mathrm{p}>0.05)$ between $0-1(-20.0 \pm 2.2 \%), 1-2$ $(-18.1 \pm 4.0 \%)$ and $2-3 \mathrm{~cm}(-19.5 \pm 0.9 \%)$. No differences ( 3 paired $t$-tests, $\mathrm{p}>0.05$ ) were found between the 3 major taxonomic groups: soft-walled $-20.0 \pm$ $1.1 \%$, calcareous $-18.4 \pm 4.1 \%$, and agglutinated $-19.2 \pm 1.7 \%$.

\section{${ }^{13} \mathrm{C}$ excess}

Higher $\delta^{13} \mathrm{C}$ in the cytoplasm of living foraminifera from incubated sediment compared to the background is attributed to the ingestion of ${ }^{13} \mathrm{C}$-labeled algae material. The $\Delta \delta^{13} \mathrm{C}$ values are positive for most of the species and indicate widespread ${ }^{13} \mathrm{C}$ enrichment (Table 2). Highest excess was observed for Trochammina globigeriniformis (2047\%o), 'other calcareous' $(1659 \%)$, and Saccorhiza ramosa (830\%), while Melonis barleeanum showed lowest excess values $\left(0.3-0.7 \%\right.$ ). A trend of decreasing ${ }^{13} \mathrm{C}$ excess with increasing depth was found for Epistominella pusilla,
Adercotryma glomerata, Cribrostomoides subglobosum, Rhabdammina abyssorum, 'other non-tubular,' and 'other tubular' agglutinated species (Fig. 4). In contrast, Globocassidulina subglobosa, Hormosinella guttifera, and S. ramosa showed higher ${ }^{13} \mathrm{C}$ excess within the sediment than at the sediment surface.

\section{Labeled carbon uptake by foraminifera}

Uptake of labeled carbon ${ }^{13} \mathrm{C}$ by benthic foraminifera was observed in all investigated sediment horizons and summed up to $815 \mu \mathrm{g} \mathrm{m}^{-2}$ (added total for $0-3 \mathrm{~cm}$, Table 2). The uptake rate was hence $0.2 \mathrm{mg}$ $\mathrm{C} \mathrm{m}^{-2} \mathrm{~d}^{-1}$ (standardized overall carbon uptake to the length of the experiment by assuming that uptake was linear). Uptake of ${ }^{13} \mathrm{C}$ was highest at the sediment surface with $574 \mu \mathrm{g} \mathrm{C} \mathrm{m}{ }^{-2}$ (sum for 0-1 cm depth) and lower within the sediment $\left(82 \mu \mathrm{g} \mathrm{C} \mathrm{m}^{-2}\right.$ at $1-2 \mathrm{~cm} ; 160 \mu \mathrm{g} \mathrm{C} \mathrm{m}^{-2}$ at $2-3 \mathrm{~cm}$ ). The 3 taxonomic groups showed enormous differences in uptake (Fig. 5). Agglutinated foraminifera contributed the most to the total uptake $(0-3 \mathrm{~cm}$; Fig. 6$)$, whereas the soft-walled saccamminids did not appear to have incorporated any of the offered ${ }^{13} \mathrm{C}$ at any sediment depth. Uptake by calcareous foraminifera was res-

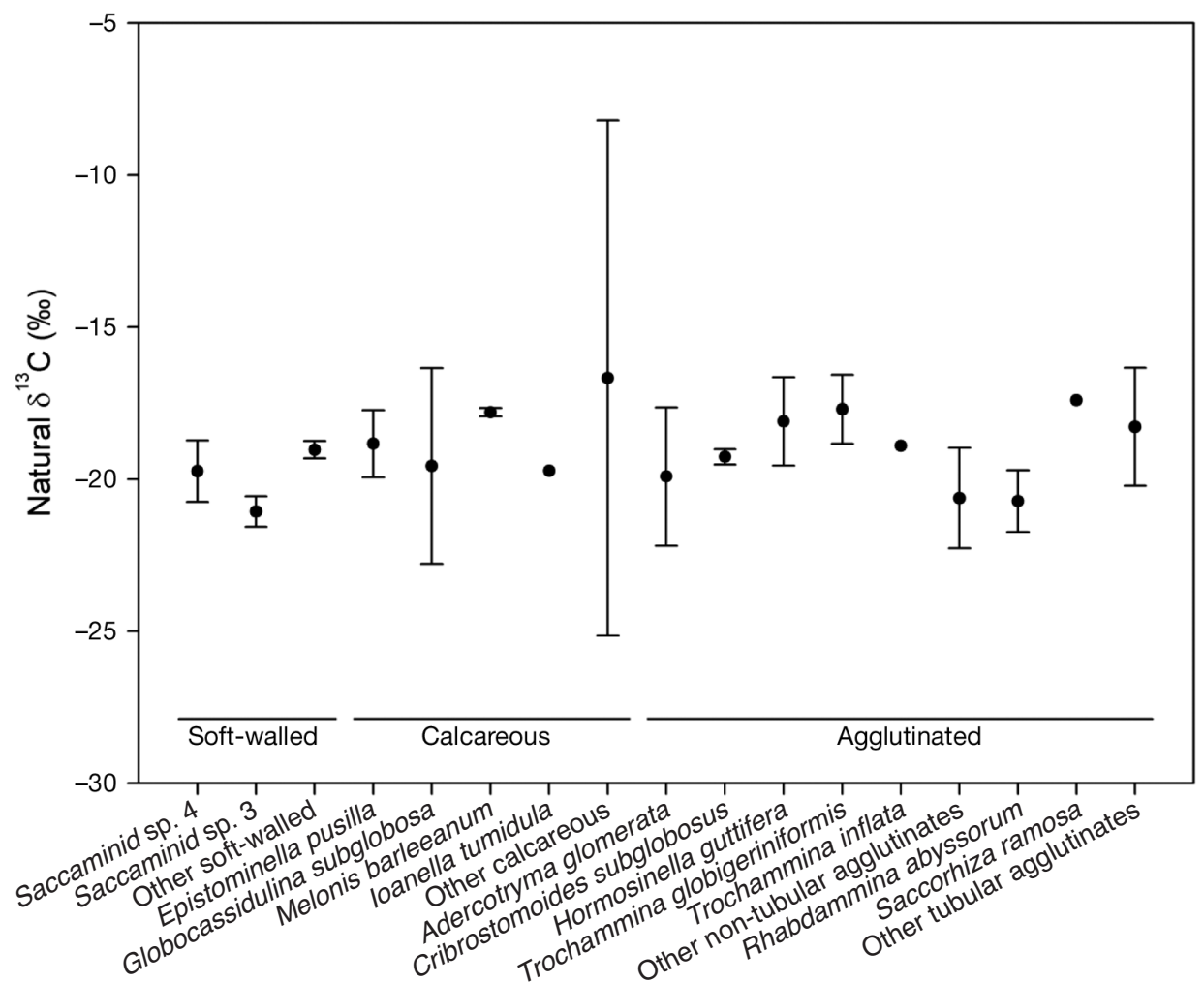

Fig. 3. Natural $\delta^{13} \mathrm{C}$ signatures (\%) of the cytoplasm of foraminifera from background sediments. Means $\pm \mathrm{SD}$ for each single species or group across the length of the sediment column (0 to $3 \mathrm{~cm}$, see Table 2$)$ 


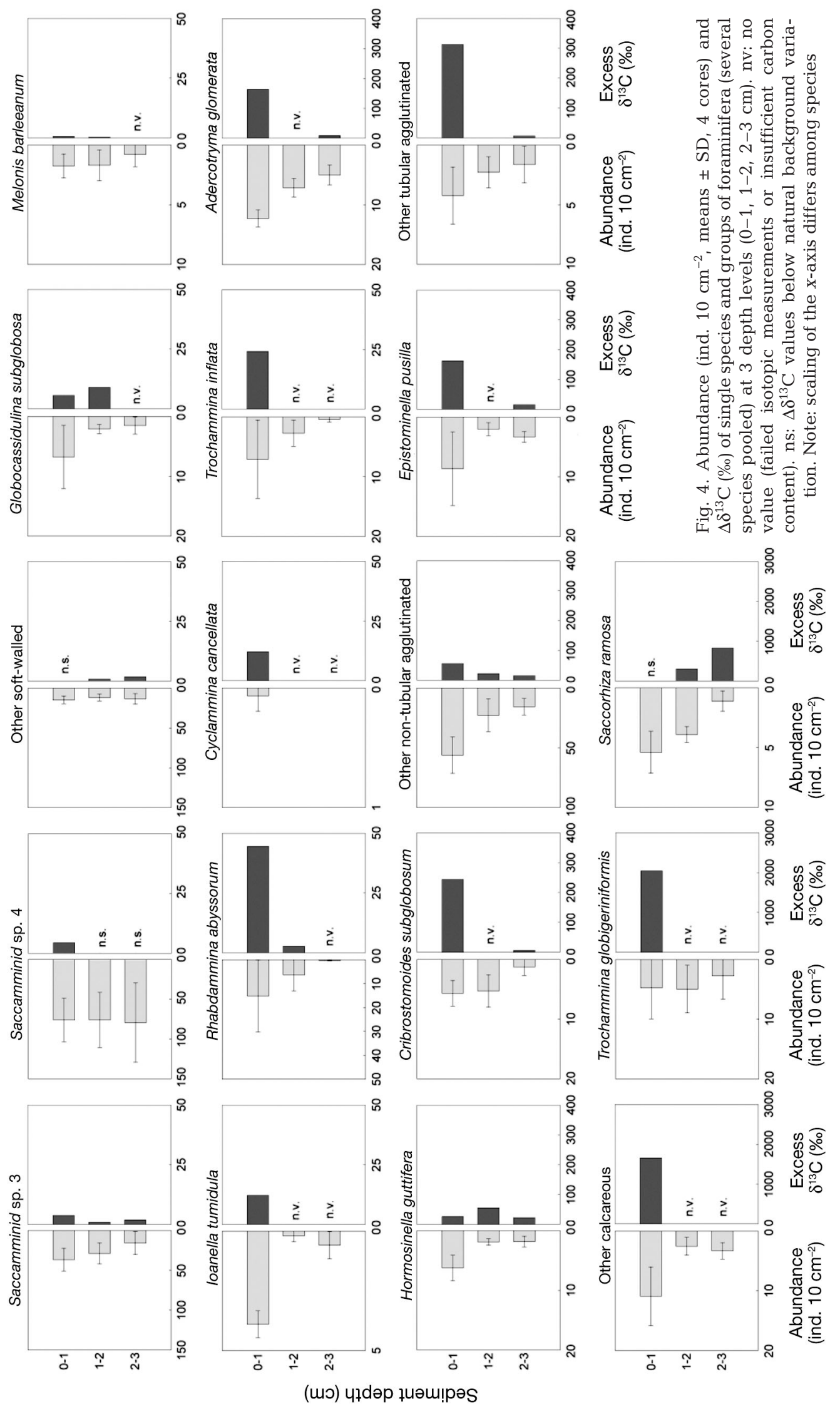




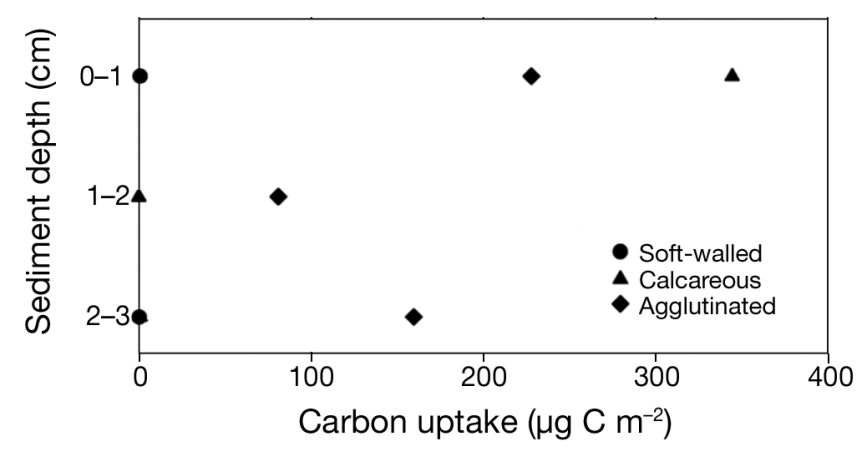

Fig. 5. Carbon uptake $\left(\mu \mathrm{g} \mathrm{C} \mathrm{m}{ }^{-2}\right.$ ) by 3 foraminiferal groups at 3 depth levels $(0-1,1-2,2-3 \mathrm{~cm})$

tricted to the sediment surface, but with the largest portion (60\%) of all groups at this depth (Fig. 5). Deeper in the sediment, the uptake of ${ }^{13} \mathrm{C}$ was exclusively linked to agglutinated foraminifera. Especially the tubular Saccorhiza ramosa showed enormous potential with $61 \%$ and $99 \%$ of the overall foraminiferal carbon uptake at $1-2 \mathrm{~cm}$ and $2-3 \mathrm{~cm}$ (Table 2). Individual species showed a very diverse response to the application of phytodetritus in terms of magnitude and depth location of the carbon uptake (Table 2). Most of the species showed maximum uptake at $0-1 \mathrm{~cm}$, and lower uptake deeper in the sediment. Highest carbon uptake $\left(>50 \mu \mathrm{g} \mathrm{C} \mathrm{m}^{-2}\right)$ was observed for $S$. ramosa $(2-3 \mathrm{~cm})$, 'other calcareous' $(0-1 \mathrm{~cm})$, 'other tubular' $(0-1 \mathrm{~cm})$, and 'other nontubular' $(0-1 \mathrm{~cm})$ agglutinated species. Cribrostomoides subglobosum, Rhabdammina abyssorum, and Trochammina globigeriniformis displayed carbon uptake between 5 and $50 \mu \mathrm{g} \mathrm{C} \mathrm{m}^{-2}$. Epistominella pusilla, Cyclammina cancellata, Aderco- tryma glomerata, and Hormosinella guttifera between 1 and $5 \mu \mathrm{g} \mathrm{C} \mathrm{m}^{-2}$, whereas soft-walled species showed uptake $\leq 0.6 \mu \mathrm{g} \mathrm{C} \mathrm{m}^{-2}$. Among the calcareous group, only E. pusilla showed any noticeable uptake $>1 \mu \mathrm{g} \mathrm{C} \mathrm{m}^{-2}$. Trochammina inflata was the only agglutinated species with a negligible response. Due to failed isotopic measurements, values are missing for A. glomerata $(1-2 \mathrm{~cm}), C$. subglobosum $(1-2 \mathrm{~cm})$, T. globigeriniformis $(1-2 \mathrm{~cm}, 2-3 \mathrm{~cm})$, and 'other calcareous' $(1-2 \mathrm{~cm}, 2-3 \mathrm{~cm})$. These 4 taxa together accounted for $16.1 \%$ and $7.6 \%$ of the total biomass of living foraminifera at $1-2 \mathrm{~cm}$ and $2-3 \mathrm{~cm}$ depth, respectively. Assuming that the isotopic analyses had therefore covered $83.9 \%(1-2 \mathrm{~cm})$ and $92.4 \%$ $(2-3 \mathrm{~cm})$ of all possible feeders, we estimated the uptake to $100 \%$ from the proportion of biomass of the missing species on the total biomass. Hence, the potential foraminiferal uptake at Stn M would have been $98 \mu \mathrm{g} \mathrm{C} \mathrm{m}^{-2}$ and $173 \mu \mathrm{g} \mathrm{C} \mathrm{m}^{-2}$ at $1-2 \mathrm{~cm}$ and 2-3 cm depth, respectively.

\section{DISCUSSION}

\section{Distribution of foraminifera}

The foraminiferal community at Stn $\mathrm{M}$ is dominated by soft-walled and agglutinated species. The presence of calcareous species and the good preservation of their shells point to an abyssal setting above the carbon compensation depth. A large proportion of monothalamous foraminifera in the total community was also observed by Nozawa et al. (2006) in the abyssal equatorial Pacific. In our experiment, abundance and biomass of living foraminifera did not dif-
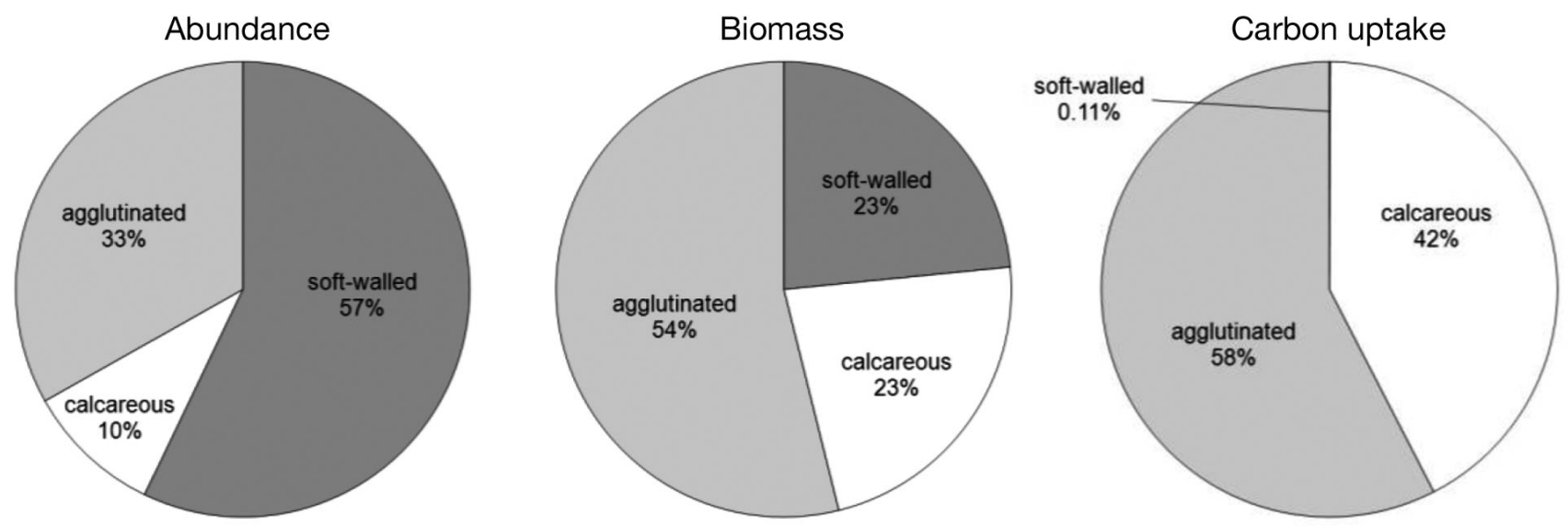

Fig. 6. Proportional contribution of the 3 foraminiferal groups to abundance, biomass (as total organic carbon, TOC), and carbon uptake 
fer among the treated and untreated sediment cores (Table 1). As the push cores were taken only several meters apart from each other it can be expected that the foraminifera in all cores were influenced by similar biotic and abiotic conditions.

The number of living foraminifera may have been overestimated, especially for species with opaque tests (miliolids and agglutinated species), since such tests could not be opened for inspection to prevent cytoplasm loss. For isotopic analysis we only used specimens that had been identified as definitely living by visibility of cytoplasm. It cannot be excluded, however, that some of the analyzed foraminifera were inhabited by foreign organisms (Gooday 1984, Grimm et al. 2007).

\section{Short-term response of the benthic community}

After $4 \mathrm{~d}$, the benthic foraminiferal community at Stn $\mathrm{M}$ had taken up $0.82 \mathrm{mg} \mathrm{C} \mathrm{m}^{-2}(0-3 \mathrm{~cm}$ sediment depth). Similar rapid responses by bathyal and abyssal foraminifera within a few days to phytodetrital pulses were observed by Moodley et al. (2002) and Nomaki et al. (2005b). Linke et al. (1995) and Gross (2000) detected fresh food material in digestive vacuoles and a greenish coloring by ingested chloroplasts in deep-sea foraminifera during a microcosm experiment within $3 \mathrm{~d}$ after feeding. We expect from other feeding experiments (Levin et al. 1999, Witte et al. 2003b, Nomaki et al. 2005b, 2011, Sweetman et al. 2009) that a longer incubation with food would have translated into higher uptake. High labeling after a $4 \mathrm{~d}$ experiment, but an overall low uptake of ${ }^{13} \mathrm{C}$ by foraminifera, was observed by Witte et al. (2003b). A significant change by foraminifera was shown after 23 d, and Witte et al. (2003b) explained this belated response to phytodetritus as a characteristic of abyssal deep-sea communities. The delayed response by foraminifera in a bathyal Norwegian fjord was attributed to the dominance of deep-infaunal species with a preference for degraded material, as well as to the larger size of the foraminifera (Sweetman et al. 2009). A slower phytodetritus ingestion by larger individuals compared to smaller specimens was observed by Nomaki et al. (2011) in Sagami Bay.

During our $4 \mathrm{~d}$ feeding experiment at Stn M benthic foraminifera demonstrated a carbon uptake rate of $0.2 \mathrm{mg} \mathrm{C} \mathrm{m}^{-2} \mathrm{~d}^{-1}$. In the abyssal North Atlantic, Witte et al. (2003b) found uptake rates of $0.1 \mathrm{mg} \mathrm{C}$ $\mathrm{m}^{-2} \mathrm{~d}^{-1}$ (8 d incubation) or $0.4 \mathrm{mg} \mathrm{C} \mathrm{m}^{-2} \mathrm{~d}^{-1}$ (23 d incubation). Carbon uptake rates by foraminifera at bathyal depths vary between 1.0 and $8.8 \mathrm{mg} \mathrm{C} \mathrm{m}^{-2} \mathrm{~d}^{-1}$
(Moodley et al. 2002, Nomaki et al. 2005b, 2006) and are higher than that at Stn $\mathrm{M}$. The flux of organic matter decreases with water depth. Also, foraminifera in shallower waters are adapted to more constant food supply. The lower response by the foraminifera at Stn $\mathrm{M}$ could be attributed to low metabolic rates caused by long periods of starvation. Also the foraminiferal biomass differed considerably between Stn $\mathrm{M}$ and the above-mentioned bathyal sites (Moodley et al. 2002, Nomaki et al. 2005b, 2006), being higher at bathyal depths. Differences in bottom water temperature (Moodley et al. 2005) or foraminiferal physiology (Nomaki et al. 2005b) may also be responsible for differences in the magnitude of uptake.

Uptake of labeled food during in situ feeding experiments at Stn M was higher for foraminifera (this study) than for the macrofauna (Sweetman \& Witte 2008b), although macrofauna was present with larger biomass and abundance. However, shorter incubation might have resulted in the lower uptake by the macrofauna. In the Northeast Atlantic at $2170 \mathrm{~m}$ depth, foraminifera and bacteria showed the same rapid response to phytodetritus while the macrofauna was less engaged (Moodley et al. 2002). At $4800 \mathrm{~m}$ depth in the North Atlantic, Witte et al. (2003b) found the macrofauna to dominate the short-term carbon uptake, while foraminifera clearly demonstrated highest carbon ingestion after $23 \mathrm{~d}$, exceeding the response by bacteria and the meiofauna (nematodes). During a $3 \mathrm{~d}$ feeding experiment in a Norwegian fjord, bacteria showed a higher carbon uptake than the macrofauna (Witte et al. 2003a).

\section{Vertical differences in carbon uptake by benthic foraminifera}

Benthic foraminifera at Stn M showed greater uptake of labeled algae at the sediment surface than deeper in the sediment (Fig. 5). The uptake of food by foraminifera depends on individual uptake rates as well as on the population density. The high standing stock of foraminifera at the sediment surface at Stn M (Fig. 2) may be associated with the high carbon uptake at in the surface layer (Fig. 4). Also, the microhabitat and food preferences are responsible for the different response times. Deep-infaunal foraminifera are not able to respond as fast as epifaunal species due to the distance to the food source. Rudnick (1989) also found delayed responses by sediment-dwelling meiobenthos in comparison to organisms at the sediment surface. Also, the preference for more degraded material, commonly present in deep-infaunal forami- 
nifera (Kitazato \& Ohga 1995), can cause a missing feeding signal in deeper sediment layers.

The changes of the $\delta^{13} \mathrm{C}$ value in sediment make it possible to follow the path of the labeled algae within the sediment column. After $4 \mathrm{~d}$, the algal material was mixed down to $2 \mathrm{~cm}$ depth (U. Witte et al. unpublished data), i.e. maximum phytodetritus penetration depth was as deep as the algal uptake by foraminifera. Highest uptake of carbon by foraminifera at the sediment level with the highest algal concentration was also observed by Nomaki et al. (2005b) at the bathyal Sagami Bay. The low response at $2-3 \mathrm{~cm}$ might be explained by the incomplete penetration of food into deeper sediment layers during the incubation time. Aberle \& Witte (2003) found highest labeling down to $5 \mathrm{~cm}$ depth after $23 \mathrm{~d}$. Hence, the incubation time in our experiment might have been too short for complete vertical transport of algal material. However, vertical mixing can be promoted by bioturbation by larger animals such as annelids within several days (Blair et al. 1996, Witte et al. 2003a). Nomaki et al. (2005b) found rapid mixing of added algae within 2 to $6 \mathrm{~d}$ down to $3 \mathrm{~cm}$ depth during their feeding experiments as a result of the activity and burrows of macrobenthic organisms. Macrofauna at Stn M is present down to $10 \mathrm{~cm}$ sediment depth (Sweetman \& Witte 2008b), but bioturbation during our experiment might have occurred at a lower rate or been more limited to the surface layer. The aforementioned macrofaunal study points out that deep-dwelling polychaetes were not as abundant as surface-dwelling species at Stn M. Therefore, we conclude that short incubation time and a low bioturbation rate might have played a role in the missing penetration of phytodetritus to deeper sediment which then did not reach infaunal species such as Melonis.

In our cores with experimental food addition, biomass and abundance of foraminifera weakly increased in the $0-2 \mathrm{~cm}$ sediment horizon after $4 \mathrm{~d}$, whereas at $2-3 \mathrm{~cm}$ depth, the trend of fewer foraminifera was found in the incubated sediment. This might suggest either reproduction induced by feeding or upward migration of species from deeper sediment layers. Nomaki et al. (2005a) observed migration by benthic foraminifera taking place only days after the food addition and concluded that reproduction and the following growth (increase of size and chamber number of the newly produced cells) require longer time periods. Laboratory experiments have shown that deep-sea foraminifera are able to move through the sediment at a speed of several millimeters per day (Hemleben \& Kitazato 1995, Gross 2000). Therefore, migration from 2 or $3 \mathrm{~cm}$ depth towards the surface during our $4 \mathrm{~d}$ incubation could have been possible, especially by foraminifera with a feeding preference for fresh phytodetritus.

\section{Carbon uptake by soft-walled foraminifera}

Soft-walled foraminifera constituted $>50 \%$ of all specimens and up to $23 \%$ of the foraminiferal biomass in Stn M sediments (Fig. 6). They showed noticeable similarities to monothalamous allogromiid species found by Gooday (2002) and Gooday et al. (2008). For the first time this group has been subject to an in situ feeding experiment using isotope labeling. Monitoring the response of soft-walled foraminifera towards phytodetritus by means of change in abundance has been carried out before. In the abyssal North Atlantic, several taxa of soft-walled Saccamminidae did not respond to phytodetritus at the sediment surface, whereas the majority of the benthic foraminifera increased in number (Gooday 1988). An important observation of our study was the lack of a short-term response of this dominating group to a nutrient-rich food source under in situ conditions, despite clear signs of vitality in form of intact tests and a high degree of test filling with cytoplasm. Although the biomass of soft-walled foraminifera at Stn M is similar to that of calcareous species, soft-walled foraminifera do not directly make use of freshly deposited phytodetritus as an energy source. On the one hand, this might be attributed to slow metabolism. Gooday et al. (2008) found monothalamous allogromiid species ingesting organic material at a slower rate than other foraminiferal species. If this also applied to the soft-walled group in our study, the lack of response might be due to the short duration of the experiment. On the other hand, soft-walled foraminifera might favor feeding strategies that do not include phytodetritus. Small monothalamous allogromiid species have been associated with bacterivory (Gooday 2002) and the ingestion of refractory organic material (Gooday et al. 2008). Bernhard \& Bowser (1992) reported exclusive feeding of allogromiid foraminifera on bacterial films, while calcareous and agglutinated foraminifera did not feed on bacteria.

\section{Carbon uptake by calcareous and agglutinated foraminifera}

Single species of calcareous and agglutinated foraminifera at Stn $M$ showed considerable differences in the uptake of phytodetritus in terms of mag- 
nitude and variation with sediment depth. We assume that several factors are responsible for the observed differences.

Epifaunal or opportunistic species show fast reaction to phytodetritus (Gooday 1993). The uptake of phytodetritus by Epistominella pusilla in our experiment (Fig. 4) is in accordance with earlier observations that have identified this small species to be opportunistic (Gooday 1993, 1996, Gooday \& Lambshead 1989, Lambshead \& Gooday 1990, Gooday \& Hughes 2002, Heinz \& Hemleben 2003, 2006) and phytophagous (Gooday et al. 2008). The agglutinated species Adercotryma glomerata also demonstrated algal uptake. This species prefers the epifaunal habitat (Gooday 1993, Heinz et al. 2001, 2002), occurring in high abundances when phytodetritus is present (Thiel et al. 1988) and showing elevated growth and reproduction (Gooday \& Hughes 2002). Cribrostomoides subglobosum showed elevated feeding rates in our experiment and may be an important species for the cycling of organic matter in the deep-sea. This species was previously found living on the sediment surface and within 0-3 $\mathrm{cm}$ sediment depth (Kaminski et al. 1988, Linke \& Lutze 1993). It can react quickly to phytoplankton settlement on the sea floor (Altenbach 1992). Saccorhiza ramosa was the only species that showed highest isotope signals deeper in the sediment, not matching its abundance maximum at the sediment surface. The agglutinated, tubular test of this species is oriented perpendicular to the sediment surface with 40 to $70 \%$ of its length buried in the sediment (Altenbach et al. 1988). Given this position and the large size of this species (several millimeters), the observed uptake maximum at $2-3 \mathrm{~cm}$ depth could be explained by transport and storage of labeled food within the sediment-covered test portion. As only a few fragments of Saccorhiza were available for analysis, the isotopic data are possibly less representative.

Deep-sea foraminifera demonstrate a high variety of dietary preferences (reviewed by Gooday et al. 2008) and selective food choice (Nomaki et al. 2006), which might explain the lack of response towards the offered phytodetritus by several species during our experiment. Food quality can also be responsible for low or non-existing uptake. Melonis barleeanum with an infaunal microhabitat (Corliss 1985, 1991, Rosoff \& Corliss 1992, Heinz et al. 2002) has an affinity for organic matter (e.g. Caralp 1989b, Loubere 1991, Schmiedl et al. 1997), and prefers degraded organic matter of lower nutritional value (Caralp 1989a, Fontanier et al. 2002, Sweetman et al. 2009). Nomaki et al. (2005b) observed shallow infaunal spe- cies to ingest ${ }^{13} \mathrm{C}$-labeled food faster and more extensively than deep-infaunal species; the latter ingested more slowly and preferred more altered food in culture experiments (Kitazato \& Ohga 1995). From their feeding experiments in a Norwegian fjord and in the North Atlantic, Witte et al. (2003b) and Sweetman et al. (2009) concluded that using fresh algae rather than more degraded organic matter and using a single algal species rather than a mixture might have caused the low uptake by benthic foraminifera.

Acknowledgements. We sincerely thank K. L. Smith Jr. and coworkers from MBARI and the officers and the crew of the $\mathrm{RV}$ 'Western Flyer' for making the realization of the experiments possible. We thank A. Gooday for help in identifying the soft-walled foraminifera. This research was supported by the Deutsche Forschungsgemeinschaft (DFG, project HE-2460/5-1) and the UK National Environmental Research Council (NERC NE/E006426/1).

\section{LITERATURE CITED}

Aberle N, Witte U (2003) Deep-sea macrofauna exposed to a simulated sedimentation event in the abyssal NE Atlantic: in situ pulse-chase experiments using ${ }^{13} \mathrm{C}$ labelled phytodetritus. Mar Ecol Prog Ser 251:37-47

Altenbach AV (1992) Short-term processes and patterns in the foraminiferal response to organic flux rates. Mar Micropaleontol 19:119-129

Altenbach AV, Struck U (2001) On the coherence of organic carbon flux and benthic foraminiferal biomass. J Foraminifer Res 31:79-85

Altenbach AV, Unsoeld G, Walger E (1988) The hydrodynamic environment of Saccorhiza ramosa (Brady). Meyniana 40:119-132

Beaulieu SE, Smith KL Jr (1998) Phytodetritus entering the benthic boundary layer and aggregated on the sea floor in the abyssal NE Pacific: macro- and microscopic composition. Deep-Sea Res II 45:781-815

- Bernhard JM, Bowser SS (1992) Bacterial biofilms as a trophic resource for certain benthic foraminifera. Mar Ecol Prog Ser 83:263-272

> Bernstein BB, Hessler RR, Smith R, Jumars PA (1978) Spatial dispersion of benthic foraminifera in the abyssal central north Pacific. Limnol Oceanogr 23:401-416

> Blair N, Levin L, DeMaster D, Plaia G (1996) The short-term fate of fresh algal carbon in continental slope sediments. Limnol Oceanogr 41:1208-1219

Caralp MH (1989a) Abundance of Bulimina exilis and Melonis barleeanum-relationship to the quality of marine organic matter. Geo-Mar Lett 9:37-43

Caralp MH (1989b) Size and morphology of the benthic foraminifer Melonis barleeanum-relationships with marine organic matter. J Foraminifer Res 19:235-245

> Corliss BH (1985) Microhabitats of benthic foraminifera within deep-sea sediments. Nature 314:435-438

Corliss BH (1991) Morphology and microhabitat preferences of benthic foraminifera from the northwest Atlantic Ocean. Mar Micropaleontol 17:195-236

> Corliss BH, Emerson S (1990) Distribution of Rose Bengal 
stained deep-sea benthic foraminifera from the Nova Scotian continental margin and Gulf of Maine. Deep-Sea Res A 37:381-400

> Drazen JC, Baldwin RJ, Smith KL Jr (1998) Sediment community response to a temporally varying food supply at an abyssal station in the NE Pacific. Deep-Sea Res II 45: 893-913

> Fontanier C, Jorissen FJ, Licari L, Alexandre A, Anschutz P, Carbonel P (2002) Live benthic foraminiferal faunas from the Bay of Biscay: faunal density, composition, and microhabitats. Deep-Sea Res I 49:751-785

Gooday AJ (1984) Records of deep-sea rhizopod tests inhabited by metazoans in the North-east Atlantic. Sarsia 69: 45-53

- Gooday AJ (1988) A response by benthic foraminifera to the deposition of phytodetritus in the deep-sea. Nature 332: 70-73

> Gooday AJ (1993) Deep-sea benthic foraminiferal species which exploit phytodetritus: characteristic features and controls on distribution. Mar Micropaleontol 22: 187-205

> Gooday AJ (1994) The biology of deep-sea foraminifera - a review of some advances and their applications in paleoceanography. Palaios 9:14-31

Gooday AJ (1996) Epifaunal and shallow infaunal foraminiferal communities at three abyssal NE Atlantic sites subject to differing phytodetritus input regimes. DeepSea Res I 43:1395-1421

Gooday AJ (2002) Organic-walled allogromiids: aspects of their occurence, diversity and ecology in marine habitats. J Foraminifer Res 32:384-399

Gooday AJ, Hughes JA (2002) Foraminifera associated with phytodetritus deposits at a bathyal site in the northern Rockall Trough (NE Atlantic): seasonal contrasts and a comparison of stained and dead assemblages. Mar Micropaleontol 46:83-110

Gooday AJ, Lambshead PJD (1989) Influence of seasonally deposited phytodetrtitus on benthic foraminferal populations in the bathyal northeast Atlantic-the species response. Mar Ecol Prog Ser 58:53-67

Gooday AJ, Levin LA, Linke P, Heeger T (1992) The role of benthic foraminifera in deep-sea food webs and carbon cycling. In: Rowe GT, Pariente V (eds) Deep-sea food chains and the global carbon cycle. Kluwer Adacemic Publishers, Dordrecht, p 63-91

Gooday AJ, Nomaki H, Kitazato H (2008) Modern deep-sea benthic foraminifera: a brief review of their morphologybased biodiversity and trophic diversity. In: Austin WEN, James RH (eds) Biogeochemical controls on palaeoceanographic environmental proxies, Vol 303. Geological Society, London, p 97-119

Grasshoff K, Kremling K, Ehrhardt M (1999) Methods of seawater analysis, 3rd edn. Wiley-VCH, Weinheim

Grimm GW, Stogerer K, Ertan KT, Kitazato H, Kucera M, Hemleben V, Hemleben C (2007) Diversity of rDNA in Chilostomella: molecular differentiation patterns and putative hermit types. Mar Micropaleontol 62:75-90

Gross O (2000) Influence of temperature, oxygen and food availability on the migrational activity of bathyal benthic foraminifera: evidence by microcosm experiments. Hydrobiologia 426:123-137

Heinz P, Hemleben C (2003) Regional and seasonal variations of recent benthic deep-sea foraminifera in the Arabian Sea. Deep-Sea Res I 50:435-447

Heinz P, Hemleben C (2006) Foraminiferal response to the
Northeast Monsoon in the western and southern Arabian Sea. Marine Micropaleontol 58:103-113

Heinz P, Kitazato H, Schmiedl G, Hemleben C (2001) Response of deep-sea benthic foraminifera from the Mediterranean Sea to simulated phytoplankton pulses under laboratory conditions. J Foraminifer Res 31:210-227

> Heinz P, Hemleben C, Kitazato H (2002) Time-response of cultured deep-sea benthic foraminifera to different algal diets. Deep-Sea Res I 49:517-537

$>$ Hemleben C, Kitazato H (1995) Deep-sea foraminifera under long time observation in the laboratory. Deep-Sea Res I 42:827-832

Hessler RR, Jumars PA (1974) Abyssal community analysis from replicate box cores in the central North Pacific. Deep-Sea Res 21:185-209

Jorissen FJ, de Stigter HC, Widmark JGV (1995) A conceptual model explaining benthic foraminiferal microhabitats. Mar Micropaleontol 26:3-15

Kaminski MA, Grassle JF, Whitlatch RB (1988) Life history and recolonization among agglutinated foraminifera in the Panama Basin. Abh Geol B-A 41:229-243

Kitazato H, Ohga T (1995) Seasonal changes in deep-sea benthic foraminiferal populations: results of long-term observations at Sagami Bay, Japan. In: Sakai H, Nozaki $\mathrm{Y}$ (eds) Biogeochemical processes and ocean flux in the western Pacific. Terra Scientific Publishing Company (TERRAPUB), Tokyo, p 331-342

> Kurbjeweit F, Schmiedl G, Schiebel R, Hemleben C, Pfannkuche O, Wallmann K, Schafer P (2000) Distribution, biomass and diversity of benthic foraminifera in relation to sediment geochemistry in the Arabian Sea. Deep-Sea Res II 47:2913-2955

> Lambshead PJD, Gooday AJ (1990) The impact of seasonally deposited phytodetritus on epifaunal and shallow infaunal benthic foraminiferal populations in the bathyal northeast Atlantic - the assemblage response. Deep-Sea Res A 37:1263-1283

> Levin LA, Blair NE, Martin CM, DeMaster DJ, Plaia G, Thomas CJ (1999) Macrofaunal processing of phytodetritus at two sites on the Carolina margin: in situ experiments using ${ }^{13} \mathrm{C}$-labeled diatoms. Mar Ecol Prog Ser 182: 37-54

Linke P, Lutze GF (1993) Microhabitat preferences of benthic foraminifera - a static concept or a dynamic adaptation to optimize food acquisition. Mar Micropaleontol 20: 215-234

Linke P, Altenbach AV, Graf G, Heeger T (1995) Response of deep-sea benthic foraminifera to a simulated sedimentation event. J Foraminiferal Res 25:75-82

> Loubere P (1991) Deep-sea benthic foraminiferal assemblage response to a surface ocean productivity gradient: a test. Paleoceanography 6:193-204

> Moodley L, Boschker HTS, Middelburg JJ, Pel R, Herman PMJ, de Deckere E, Heip CHR (2000) Ecological significance of benthic foraminifera: ${ }^{13} \mathrm{C}$ labelling experiments. Mar Ecol Prog Ser 202:289-295

> Moodley L, Middelburg JJ, Boschker HTS, Duineveld GCA, Pel R, Herman PMJ, Heip CHR (2002) Bacteria and foraminifera: key players in a short-term deep-sea benthic response to phytodetritus. Mar Ecol Prog Ser 236: 23-29

Moodley L, Middelburg JJ, Soetaert K, Boschker HTS, Herman PMJ, Heip CHR (2005) Similar rapid response to phytodetritus deposition in shallow and deep-sea sediments. J Mar Res 63:457-469 
Nomaki H, Heinz P, Hemleben C, Kitazato H (2005a) Behavior and response of deep-sea benthic foraminifera to freshly supplied organic matter: a laboratory feeding experiment in microcosm environments. J Foraminifer Res 35:103-113

Nomaki H, Heinz P, Nakatsuka T, Shimanaga M, Kitazato H (2005b) Species-specific ingestion of organic carbon by deep-sea benthic foraminifera and meiobenthos: in situ tracer experiments. Limnol Oceanogr 50:134-146

Nomaki H, Heinz P, Nakatsuka T, Shimanaga M and others (2006) Different ingestion patterns of ${ }^{13} \mathrm{C}$-labeled bacteria and algae by deep-sea benthic foraminifera. Mar Ecol Prog Ser 310:95-108

Nomaki H, Ohkouchi N, Heinz P, Suga H and others (2009) Degradation of algal lipids by deep-sea benthic foraminifera: an in situ tracer experiment. Deep-Sea Res I 56: 1488-1503

- Nomaki H, Ogawa NO, Takano Y, Suga H, Ohkouchi N, Kitazato H (2011) Differing utilization of glucose and algal particulate organic matter by deep-sea benthic organisms of Sagami Bay, Japan. Mar Ecol Prog Ser 431: $11-24$

Nozawa F, Kitazato H, Tsuchiya M, Gooday AJ (2006) 'Live' benthic foraminifera at an abyssal site in the equatorial Pacific nodule province: abundance, diversity and taxonomic composition. Deep-Sea Res I 53:1406-1422

Ogawa NO, Nagata T, Kitazato H, Ohkouchi N (2010) Ultrasensitive elemental analyzer/isotope ratio mass spectrometer for stable nitrogen and carbon isotope analyses. In: Ohkouchi N, Tayasu I, Koba K (eds) Earth, life, and isotopes. Kyoto University Press, Kyoto, p 339-353

Reimers CE (1987) An in situ microprofiling instrument for measuring interfacial pore water gradients: methods and oxygen profiles from the north Pacific Ocean. Deep-Sea Res II 334:2019-2035

Rosoff DB, Corliss BH (1992) An analysis of recent deep-sea benthic foraminiferal morphotypes from the Norwegian and Greenland Seas. Palaeogeogr Palaeoclimatol Palaeoecol 91:13-20

Rudnick DT (1989) Time lags between the deposition and meiobenthic assimilation of phytodetritus. Mar Ecol Prog Ser 50:231-240

Ruhl HA, Smith KL Jr (2004) Shifts in deep-sea community structure linked to climate and food supply. Science 305: 513-515

Schmiedl G, Mackensen A, Muller PJ (1997) Recent benthic foraminifera from the eastern South Atlantic Ocean: dependence on food supply and water masses. Mar Micropaleontol 32:249-287

Editorial responsibility: Matthias Seaman, Oldendorf/Luhe, Germany
Smith KL Jr, Druffel ERM (1998) Long time-series monitoring of an abyssal site in the NE Pacific: an introduction. Deep-Sea Res II 45:573-586

Smith KL Jr, Kaufmann RS, Baldwin RJ (1994) Coupling of near-bottom pelagic and benthic processes at abyssal depths in the eastern north Pacific Ocean. Limnol Oceanogr 39:1101-1118

Smith KL Jr, Kaufmann R, Baldwin R, Carlucci A (2001) Pelagic-benthic coupling in the abyssal eastern North Pacific: an 8-year time-series study of food supply and demand. Limnol Oceanogr 46:543-556

Smith KL Jr, Baldwin RJ, Ruhl HA, Kahru M, Mitchell BG, Kaufmann RS (2006) Climate effect on food supply to depths greater than 4,000 meters in the northeast Pacific. Limnol Oceanogr 51:166-176

Smith KL Jr, Ruhl H, Kaufmann R, Kahru M (2008) Tracing abyssal food supply back to upper-ocean processes over a 17-year time series in the northeast Pacific. Limnol Oceanogr 53:2655-2667

Smith KL Jr, Ruhl HA, Bett BJ, Billett DSM, Lampitt RS, Kaufmann RS (2009) Climate, carbon cycling, and deep-ocean ecosystems. Proc Natl Acad Sci USA 106: 19211-19218

Snider LJ, Burnett BR, Hessler RR (1984) The composition and distribution of meiofauna and nanobiota in a central North Pacific deep-sea area. Deep-Sea Res A 31: 1225-1249

Sweetman AK, Witte U (2008a) Macrofaunal response to phytodetritus in a bathyal Norwegian fjord. Deep-Sea Res I 55:1503-1514

Sweetman AK, Witte U (2008b) Response of an abyssal macrofaunal community to a phytodetrital pulse. Mar Ecol Prog Ser 355:73-84

Sweetman AK, Sommer S, Pfannkuche O, Witte U (2009) Retarded response by macrofauna-size foraminifera to phytodetritus in a deep Norwegian fjord. J Foraminifer Res 39:15-22

Thiel H, Pfannkuche O, Schriever G, Lochte K and others (1988) Phytodetritus on the deep-sea floor in a central oceanic region of the northeast Atlantic. Biol Oceanogr 6: 203-239

- Witte U, Aberle N, Sand M, Wenzhofer F (2003a) Rapid response of a deep-sea benthic community to POM enrichment: an in situ experimental study. Mar Ecol Prog Ser 251:27-36

Witte U, Wenzhofer F, Sommer S, Boetius A and others (2003b) In situ experimental evidence of the fate of a phytodetritus pulse at the abyssal sea floor. Nature 424 : 763-766

Submitted: March 7, 2011; Accepted: July 18, 2011 Proofs received from author(s): September 16, 2011 